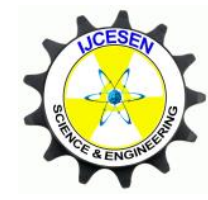

Copyright (C) IJCESEN
International Journal of Computational and

Experimental $\boldsymbol{S}$ cience and Engineering

(IJCESEN)

Vol. 4-No.3 (2018) pp. 39-42

http://dergipark.gov.tr/ijcesen

Research Article

\title{
Comparison of Bearing Capacity of Piled Raft Foundations Consisting of Different Number of Piles under Static and Repetitive Loads
}

\section{Baki BAGRIAÇIK ${ }^{1 *}$,Sefer Ercan EPSILELI ${ }^{1}$, Emre PINARCI $^{2}$ and Mustafa BELEN ${ }^{2}$}

\author{
${ }^{1}$ Cukurova University, Engineering Faculty, Civil Engineering Department, 01330, Adana-Turkey \\ * Corresponding Author : bakibagriacik@gmail.com \\ ORCID:0000-0002-1860-2881
}

${ }^{2}$ Cukurova University, Engineering Faculty, Geology Engineering Department, 01330, Adana-Turkey

\section{$\underline{\text { Article Info: }}$ \\ $\underline{\text { Keywords }}$ \\ Repetitive load \\ Static load \\ Sandy soil \\ Piled raft foundation}

DOI: $10.22399 /$ ijcesen. 477263

Received : 1 November 2018

Accepted : 26 November 2018

\begin{abstract}
$\underline{\text { Abstract: }}$
In this study, large-scale experiments have been carried out at 5th Regional Research and Development Headquarters Engineering of Highways in order to determine the contribution of the piles in the pile-raft foundation to the bearing capacity. The bearing capacity were determined for only the raft, the raft with single pile and the raft with four pile under static and repetitive loading. In the examinations, sand samples which were taken from a river bed were used. The sand was classified as uniform clean sand (SP) according to standarts. As a result of study following results were obtained. Only raft has reached lowest bearing capacity at different alternatives under static loading. When used single pile and four piles at piled raft foundation systems, the bearing capacity has increased by 1.130 and 2.52 respectively under static loading. As the number of piles increased, it was observed that the settlements at piled raft foundations under the same repetitive loading decrease.
\end{abstract}

\section{Introduction}

In recent years, due to the increasing population and decreasing land use requirements, there have been improvements in civil engineering applications. In order to meet the growing population needs, it has become necessary to plan and build multi-storey high-rise buildings in soft and loose ground conditions. During the planning of such structures, they are exposed to large static and dynamic loads such as their own weight, earthquake and wind of the structures should be considered. If these effects are taken into consideration, the loads to be transferred to the soil has reached the most extreme values. In this case, shallow foundations may be insufficient in terms of settlement and the bearing capacity. Piled raft foundations is most widely used for solve these problems. The piled raft foundations are generally not economical, according to the shallow foundations. But, they transport the load from structure to the soil layers with sufficient bearing capacity. There are a lot of studies about piled raft foundations. These studies were summaried below. One of the most important parameters of the determining bearing capacity at piled raft foundations while designing is the distance between piles. Determining the optimum value of the distance between piles make enough bearing capacity and settlement as well as economical designing of the piled raft foundation. In the literature, there are generally theoretical studies and numerical studies based on software packages like finite elements and boundary elements for determining to this parameters $[1,2,3]$. In these studies, it's stated that optimum distance between piles should be 2.5 times to 12.0 times the diameter of the pile. There are also experimental studies for determining for an optimum distance between piles in the literature. According to results of these experimental studies, optimum distance between piles should be 3 times to 4 times of the pile's diameter $[4,5,6,7,8,9,10]$. Another parameter affects the optimum distance between piles on the piled raft foundation design is the determining how to change the load proportions 
between piles and raft foundation. As mentioned in the literature, experimental studies in order to be able to determine load proportions between piles and raft foundation are very limited. In general, these parameters had determined by using theoretical studies, software packages based on finite and boundary elements methods. It's determined that according to the studies conducted by finite and boundary elements methods on the piled raft foundations, bearing capacity's $15 \%-40 \%$ carried by raft foundation and $85 \%-60 \%$ carried by the piles $[11,12,13,14]$. Parameters like diameters of piles, configurations, and properties of installed soil also have importance for piled raft foundations. Although there are a limited number of experimental studies to determine these parameters [14], in general, many theoretical studies and the studies done by software packages based on finite and boundary elements exist $[1,2,3]$. The parameters obtained from these studies is also over a wide range. When looked to literature, there are a lot of studies about piled raft foundations. But, in the literature, there is not much experimental work carried out under static and repetitive loads to investigate the different parameters of piled raft foundations embedded in sandy soils. So, this paper aim to determine the bearing capacity for only the raft, the raft with single pile and the raft with four pile under static and repetitive loading.

\section{Material and Method}

The model tests were conducted in the Research and Development Laboratory of 5th Regional Directorate of Highways, using by big scale cyclic plate loading system. The testing equipment consists of the test case, loading unit, data logger, and software (Figure 1 and Figure 2). The test box is designed as a rigid and length, width and height $2 \mathrm{~m}$. The model raft and model piles were produced from steel which has stiffness $210000 \mathrm{Mpa}$, unit weight 77 $\mathrm{kN} / \mathrm{m}^{2}$. The model raft foundation's width, length and thickness are respectively $300 \mathrm{~mm}, 300 \mathrm{~mm}$ and $20 \mathrm{~mm}$ (Figure 3). The model pile's dimension and length are $0.05 \mathrm{~m}$ and $0.4 \mathrm{~m}$ respectively (Figure 3 ). The actuator produce monotonic or repeated loads to a maximum capacity of $245 \mathrm{kN}$. This actuator give different amplitudes and frequencies which produce static and cycling load with electromechanical control system. In order to determine the values of the load and settlement which were applied on the foundation plate, an electronic load cell and a Linear Variable Displacement Transformer (LVDT) were used. In the examinations, sand samples which were taken from river bed were used. Experiments were performed at soil mechanics laboratory on ovendried sand samples. The sand was determined as uniform clean sand (SP) according to ASTM [15], Percentage of Medium Grained Sand \% 46.40, Percentage of Fine Grained Sand is \% 53.60, Maximum Dry Specific Gravity is $17.06 \mathrm{kN} / \mathrm{m}^{3}$, Minimum Dry Specific Gravity is $15.03 \mathrm{kN} / \mathrm{m}^{3}$ and Specific Gravity is $26.80 \mathrm{kN} / \mathrm{m}^{3}$. Test procedure are given below. The side faces of the test case were scaled as $10 \mathrm{~cm}$ for placement of the sand to the test case for desired density by layers. The required sand for $10 \mathrm{~cm}$ layer was poured into the test case from a distance as close as possible, after that spreaded along the surface of

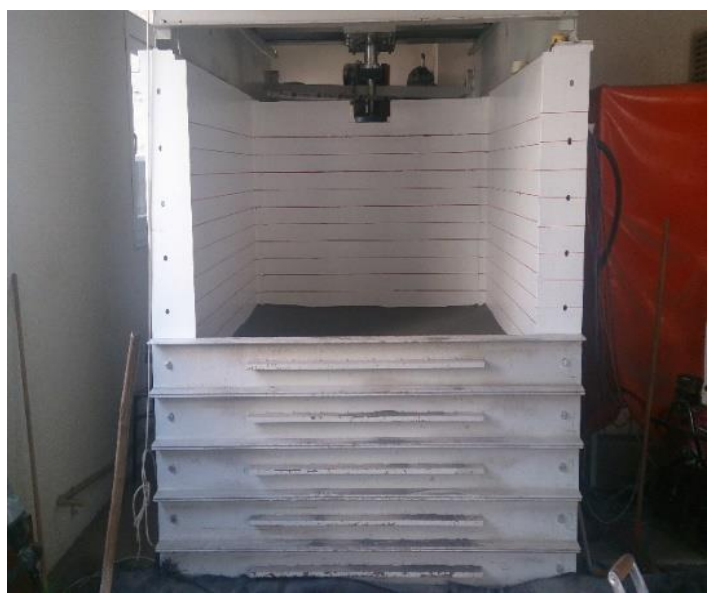

Figure 1. Test Box

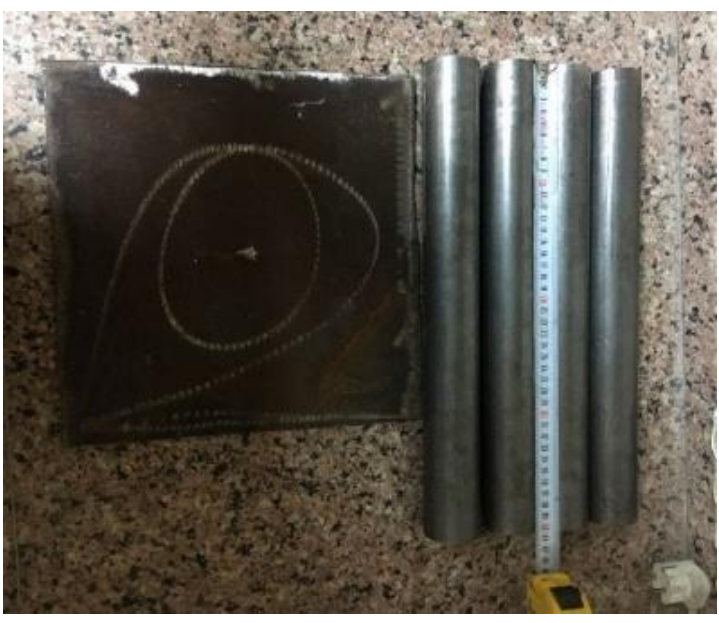

Figure2. Model Piles and Raft Foundation

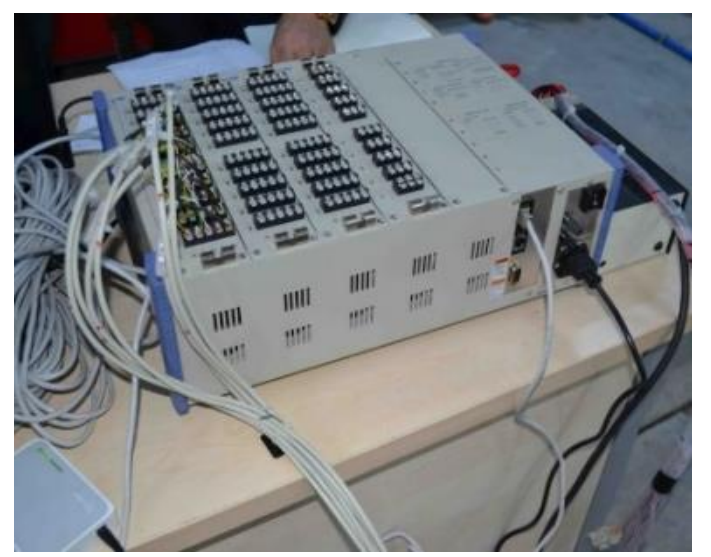

Figure3. Data Acquisition System 
the case with the help of a trowel. The sand has smoothened and spreaded homogeneously without applying pressure using thin wooden plates. After compaction is complete, the piled raft foundation plate was placed on the surface of the soil and embeded into the soil using loader systems with a constant penetration rate $[14,16]$. As soon as the base of the raft foundation contacts the surface of the soil, the loading was stopped, controlled with a spirit level and the surface smoothness was provided. Prior to the test measuring systems was placed to the test test setup. The measuring systems includes two vertical displacement gauges placed two sides on the foundation plate, and the load cell. The initial values of the measuring systems were reset, and final necessary controls were made for the load to be applied effect uniformly and for the smoothness of the system. The load was applied vertically to the foundation plate center and static and repetitive loads. The loading rate was kept constant during the test. After the tests were completed, the obtained load-displacement curves transferred to datalogger device and converted to digital values via software. After every test, bearing capacities were determined by plotting vertical load-settlement curves.

\section{Results and Discussions}

In this study, the behaviors of piled raft foundation consisting of four piles in two different configuration under static and repetitive loading conditions were investigated by large scale laboratory tests. The findings obtained from the experimental results were shown as Figure 4 and Figure 5 under static and repetitive loads. The bearing capacity is defined as the vertical displacement value corresponding to 10 percent of the raft foundation. All the test results were interpreted using this approach. The bearing capacity for raft foundation, piled raft foundation at single pile and for piled raft foundation at four piles are $41.150 \mathrm{kN}, 46.400 \mathrm{kN}$ and $103.715 \mathrm{kN}$ respectively from Figure 4. It has been determined that the lowest bearing capacity is the only raft foundation. It has seen that the use of piles from 1 to 4 has increased the bearing capacity at a considerable rate. From figure 5, as the number of piles increased, it was observed that the settlements (displacement) at piled raft foundations under the same repetitive loading decrease from nearly $5.5 \mathrm{~cm}$ to $3.5 \mathrm{~cm}$.

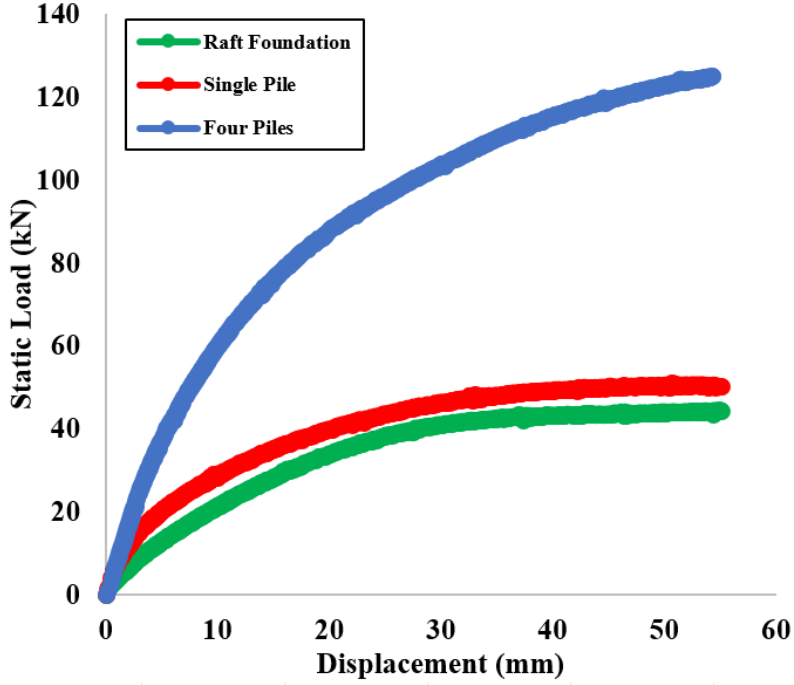

Figure 4. The load-displacement graphics for static loading.

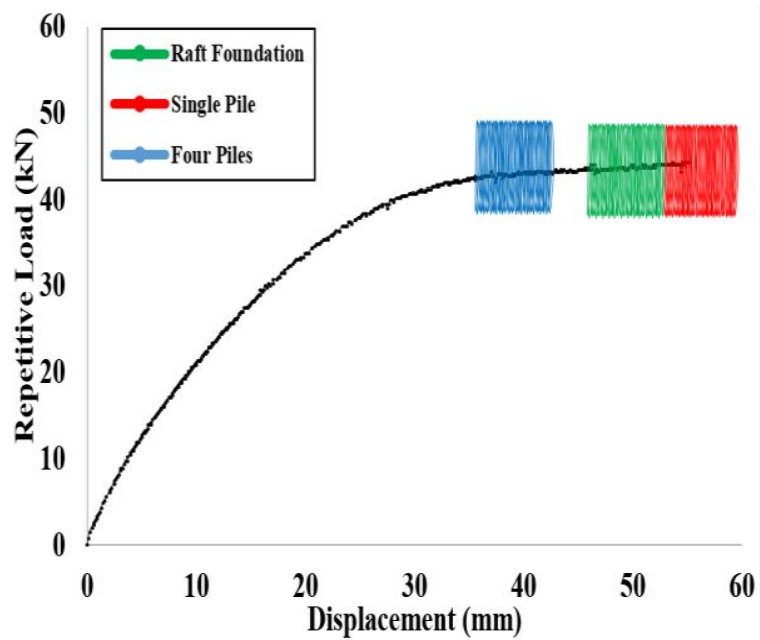

Figure 5. The load-displacement graphics for repetitive loading.

\section{Conclusions}

This paper aim to determine the bearing capacity for only the raft, the raft with single pile and the raft with four pile under static and repetitive loading. As a result of the study, the following results were obtained.

- The bearing capacity for raft foundation, piled raft foundation at single pile and for piled raft foundation at four piles are 41.150 $\mathrm{kN}, 46.400 \mathrm{kN}$ and $103.715 \mathrm{kN}$ respectively.

- It has been determined that the lowest bearing capacity is the only raft foundation.

- When used single pile and four piles at piled raft foundation systems, the bearing capacity has increased by 1.130 and 2.52 respectively under static loading. 
- $\quad$ It has seen that the use of piles from 1 to 4 has increased the bearing capacity at a considerable rate.

- As the number of piles increased, it was observed that the settlements at piled raft foundations under the same repetitive loading decrease.

\section{Acknowledgement}

The tests were performed in the 5th Regional Research-Development Headquarters Engineering of Highways and Cukurova University Scientific Research Project Unit (Project Number: FBA-20178425) which is acknowledged.

\section{References}

[1] M. J. Tomlinson, Pile Design And Construction Practice, Chapman And Hall, London, UK, 2004.

[2] N. Erdemir and V. Okur, Kazık Gruplarının Sismik Etki Altındaki Performansı, Eskişehir Osmangazi Üniversitesi Mühendislik Mimarlık Fakültesi Dergisi. Sayı. 24, No.1, s. 91-107, 2011.

[3] A. G. Yazici, Kazıklar Arası Mesafenin Kazıklı Radye Temel Sisteminde Etkisinin İki ve Üç Boyutlu Analizi. Yüksek Lisans Tezi, Niğde Üniversitesi, Fen Bilimleri Enstitüsü, Niğde, 75s, 2013.

[4] T. Whitaker, Some Experiments on Model Piled Foundations in Clay, 6th International Congress of International Association of Bridge Structure Engineering, Stockholm, Sweden, pp. 124-139, 1961.

[5] H. Kishida, K. Matsushita and I. Sakamoto, SoilStructure Interaction of the Elevator Tower and Concrete Footings. Proceedings of the 4th World Conference on Earthquake Engineering, Vol. 3, Santiago de Chile, pp 101-115, 1969.

[6] A. Tejchman, Model Investigation of Pile Groups in Sand, Journal of the Soil Mechanics Foundation Division, ASCE, USA, Vol. 99, No. SM2, 199-217, 1973.

[7] D. L. York and R. J. Leahy, Experiences with Heave and Relaxation of End Bearing Piles. Associated Pile and Fitting Corp. Pile Talk Seminer, New York, pp. 73-85,1979.

[8] R. W. Cooke, Piled Raft Foundations on Stiff ClaysA Contribution to Design Philosophy, Géotechnique, Vol. 36, No:2, pp. 169-203,1986.

[9] D. D. Sönmez, Orta Sıkılıktaki Kumdaki Kazık Gruplarının Negatif Sürtünmesi ile İlgili Bir Model Çalışma, Yüksek Lisans Tezi, Orta Doğu Teknik Üniversitesi, Fen Bilimleri Enstitüsü, Ankara, 89s, 1994.

[10] N. F. Ismael, Axial Load Tests on Pile and Pile Group in Cemented Sands, Journal of Geotechnical and Geoenvironmental Engineering. pp 767-773, 2001.

[11] R. Butterfield and P. K. Banerjee, The Problem of Pile Group-Pile Cap Interaction, Géotechnique, Volume 21, No:2, pp. 135-142, 1971.
[12] F. Kuwabara, An Elastic Analysis for Piled Raft Foundations in Homogeneous Soils, Soils and Foundations, Vol. 29, No:1, pp. 82-92,1989.

[13] M. U. Ergun ve H. K. Türkmen, Kazıklı Radye Temellerin Etkin Tasarımı. 103 I007 nolu Tübitak Projesi, Ankara, 2007.

[14] D. D. C. Nguyen, S. B. Jo and D. S. Kim, Design Method of Piled-Raft Foundations Under Vertical Load Considering Interaction Effects, Computers and Geotechnics, Vol. 47, pp. 16-27, 2013.

[15] ASTM D422, Standard Test Method for Particle-Size Analysis of Soils.

[16] S. Gök, Kazıklı Radye Temellerin Analizi. Doktora Tezi, İstanbul Teknik Üniversitesi, Fen Bilimleri Enstitüsü, İstanbul, 101s, 2007. 